\title{
Pharmacological enhancement of mGluR5 facilitates contextual fear memory extinction
}

\author{
Ferzin Sethna ${ }^{1}$ and Hongbing Wang ${ }^{2,3}$ \\ ${ }^{1}$ Genetics Program, ${ }^{2}$ Department of Physiology, ${ }^{3}$ Neuroscience Program, Michigan State University, East Lansing, Michigan \\ 48824, USA
}

\begin{abstract}
Behavioral exposure therapy, which involves extinction of the previously acquired fear, has been used to treat anxietyrelated symptoms such as post-traumatic stress disorder. It has been hypothesized that proextinction pharmacotherapeutics may enhance the efficacy of exposure therapy. Systemic administration of the metabotropic glutamate receptor 5 (mGluR5)-positive allosteric modulator 3-cyano- $\mathrm{N}$-(1,3-diphenyl-1H-pyrazol-5-yl)benzamide (CDPPB) facilitated the extinction of contextual fear memory. Notably, CDPPB also enhanced the initial fear memory formation, and had no effect on memory retrieval. Our data suggest that positive regulation of mGluR5 may offer a new method to enhance exposure therapy through facilitating extinction without adversely affecting other aspects of memory process.
\end{abstract}

[Supplemental material is available for this article.]

Experiencing an extremely traumatic event can sometimes lead to dysregulated fear, which manifests itself as post-traumatic stress disorder (PTSD) or other fear-related symptoms such as anxiety disorder (Kearns et al. 2012). It is estimated that PTSD and anxiety disorders affect $5 \%-10 \%$ and $18 \%$ of the population, respectively, in the USA. Majority of people who experience trauma show hyperarousal, which declines over time. However, the hyperarousal in PTSD patients remains persistent, possibly due to impaired fear memory extinction (Kearns et al. 2012; Parsons and Ressler 2013). In order to reduce fear response linked to certain situations, individuals must incorporate new learning and form a corrective memory such that the situation is no longer associated with the traumatic event (Myers and Davis 2007; Maren 2011). This is the same process that occurs in memory extinction, during which the frequency or magnitude of the conditioned response decreases upon repeated or prolonged exposure to a cue (i.e., the conditioned stimulus) in the absence of the unconditioned stimulus. Indeed, extinction has been successfully used in exposure therapy, which involves gradual exposure to the fear-causing stimulus in the absence of an aversive event (Quirk et al. 2010; Kearns et al. 2012). Thus, application of proextinction agents along with exposure therapy may improve the efficacy and outcome of PTSD treatment (Choi et al. 2010).

Glutamate transmission, which is mediated by ionotropic and metabotropic glutamate receptors (iGluR and mGluR), regulates both long-term potentiation (LTP) and long-term depression (LTD) as well as learning and memory formation. Potentiation of iGluRs including NMDAR and AMPAR normally leads to the facilitation of learning and extinction (Tang et al. 1999; Yamada et al. 2009; Myers et al. 2011). Inhibition of these receptors impairs learning and extinction. Notably, the partial NMDAR agonist D-cycloserine (DCS) has been effectively used in combination with exposure therapy for several fear and anxiety abnormalities such as panic disorder, social anxiety disorder, obsessive-compulsive disorder, and PTSD (Kushner et al. 2007; Otto et al. 2010; Myers et al. 2011; Difede et al. 2014). Recently, targeting the mod- ulatory mGluRs has been increasingly popular for therapeutic approaches due to fewer serious side effects such as memory loss, disorientation, psychosis, and hallucinations (Cleva and Olive 2011). Among the mGluRs, mGluR5 is found to physically interact with NMDAR, and its activation potentiates NMDAR function (Awad et al. 2000; Cleva and Olive 2011). Genetic deletion and pharmacological inhibition of mGluR5 leads to impairments in the acquisition of fear memory and extinction ( $\mathrm{Lu}$ et al. 1997; Rodrigues et al. 2002; Xu et al. 2009; Fontanez-Nuin et al. 2011). Thus, positive modulation of mGluR5 may represent an attractive approach to facilitate both the initial learning and the inhibitory learning during extinction. In support of this idea, the mGluR5-positive allosteric modulator (PAM) CDPPB (3-cyano- $N$-(1,3-diphenyl-1H-pyrazol-5-yl)benzamide) enhances the extinction learning following methamphetamine (Kufahl et al. 2012), ethanol (Gass et al. 2014), and cocaine selfadministration (Cleva et al. 2011). CDPPB also facilitates the extinction of conditioned place preference memory associated with cocaine (Gass and Olive 2009). Consistent with the notion that the prefrontal cortex (PFC) is involved in inhibitory learning during extinction, neuroplasticity, and neuronal firing in the PFC are altered following the extinction of drug seeking and the administration of CDPPB (Lecourtier et al. 2007; Knackstedt et al. 2010; Ghasemzadeh et al. 2011; Gass et al. 2014). However, the effect of mGluR5 PAM on regulating fear memory extinction remains unknown.

Here, we examined the effect CDPPB on contextual fear memory extinction. All experiments were performed with 2- to 3-mo-old male C57BL6 mice, and all manipulations were in compliance with the guidelines of Institutional Animal Care and Use Committee at Michigan State University. As shown in Figure 1A1, mice were first trained by contextual fear conditioning, during which animals received a single mild footshock $(0.7 \mathrm{~mA}, 2 \mathrm{sec})$.

2014 Sethna and Wang This article is distributed exclusively by Cold Spring Harbor Laboratory Press for the first 12 months after the full-issue publication date (see http://learnmem.cshlp.org/site/misc/terms.xhtml). After 12 months, it is available under a Creative Commons License (AttributionNonCommercial 4.0 International), as described at http://creativecommons .org/licenses/by-nc/4.0/. 


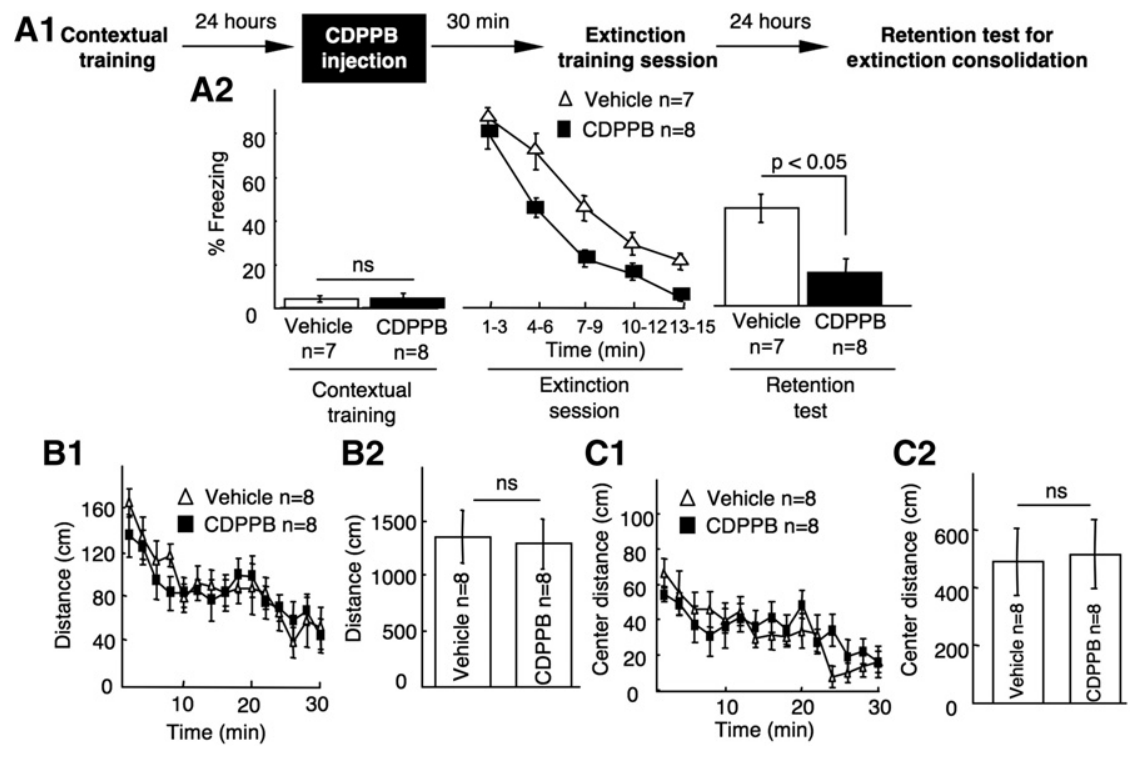

Figure 1. CDPPB facilitates contextual fear memory extinction. (A1) Behavioral and CDPPB administration procedure. During contextual training, a mouse was placed in a contextual chamber with dimensions of $28 \mathrm{~cm}$ (length) $\times 28 \mathrm{~cm}$ (width) $\times 34 \mathrm{~cm}$ (height) for 2 min before receiving a mild footshock $(0.7 \mathrm{~mA}, 2 \mathrm{sec})$. Following the footshock, the mouse was left in the chamber for $1 \mathrm{~min}$ before returning to its home cages. The extinction training was performed $24 \mathrm{~h}$ later, during which the mouse was re-exposed to the contextual chamber for $15 \mathrm{~min}$. To determine extinction consolidation, the mouse was reintroduced into the chamber for $2 \mathrm{~min} 24 \mathrm{~h}$ after extinction training. Freezing behavior at every 10 -sec interval was scored by the observer. (A2) Mean \pm SEM of percentage of freezing per minute during contextual training, extinction session, and extinction retention test as indicated. (B1) Mean \pm SEM of distance traveled for each of the 2-min bin during the 30-min open field test in the contextual training chamber. (B2) Mean \pm SEM of the total distance traveled during the 30-min open field test. (C1) Mean \pm SEM of distance traveled in the center area for each of the 2-min bin during the 30 -min open field test. (C2) Mean \pm SEM of the total distance traveled in the center area during the 30-min open field test. Two-way repeated-measures ANOVA (data from the extinction session and open field) or Student's $t$-test (data from the contextual training, retention test, and total activity in the open field test) were used for data analysis. (ns) Not significantly different.

Twenty-four hours later, mice receiving intraperitoneal injection of vehicle (10\% DMSO) or CDPPB (20 mg/kg in $10 \%$ DMSO) were subjected to a 15-min extinction session. Both groups showed significant freezing (Fig. 1A2) and reduced ambulatory movement (Supplemental Fig. S1) during the first 3 min of the extinction session, indicating that potentiation of mGluR5 by CDPPB did not affect memory retrieval (or expression). Compared with the vehicle-injected group, mice receiving CDPPB showed more decrease in freezing (Fig. 1A2; $F_{(1,13)}=5.01, P<0.05$ ) and more increase in movement (Supplemental Fig. S1; $F_{(1,13)}=$ $6.39, P<0.05$ ) within the 15 -min extinction session.

To test the retention of contextual memory extinction, we examined the conditioned fear response $24 \mathrm{~h}$ following the extinction session (Fig. 1A1). The facilitated fear extinction in the CDPPB group was preserved, as indicated by less freezing (Fig. 1A2) and more movement (Supplemental Fig. S1) during the retention test. These results demonstrate that enhancement of mGluR5 activity facilitates the extinction process.

Since the CDPPB-injected mice showed less freezing and therefore more locomotor activity during the extinction session, we tested whether CDPPB caused a general increase in locomotor activity. Another cohort of mice injected with CDPPB showed similar ambulatory movement to the vehicle-injected group in the contextual training chamber (Fig. $1 \mathrm{~B} 1, F_{(1,14)}=1.73, P>$ 0.05; Fig. 1B2, $P>0.05)$. CDPPB- and the vehicle-injected mice also showed similar locomotor activity in the center of the chamber (Fig. 1C1, C2), indicating that CDPPB did not affect the anxiety level. This demonstrates that the increased rate of extinction in the CDPPB-injected mice is not due to the drug effects on locomotor activity or anxiety.

It is possible that CDPPB administered before extinction could simply degrade the contextual memory and thus result in reduced fear during the subsequent retention test. To test this possibility, we injected another cohort of mice with vehicle or CDPPB $24 \mathrm{~h}$ after training and then tested the contextual fear memory $24 \mathrm{~h}$ after the injection (Fig. 2A). The vehicle- and CDPPB-injected mice showed similar freezing (Fig. 2B1) as well as movement (Fig. 2B2) during testing. This indicates that CDPPB in the absence of the extinction protocol does not alter contextual fear memory.

Previous studies have suggested that memory extinction and the initial memory formation may be regulated by opposing mechanisms. For instance, reduction of cAMP signaling impairs memory formation but facilitates extinction (Abel et al. 1997; Isiegas et al. 2006); enhancement of cAMP facilitates fear memory formation but impairs extinction (Wang et al. 2004; Monti et al. 2006). We further examined whether mGluR5 potentiation also has procognitive effect on the initial fear memory formation (Fig. 3A). After receiving CDPPB or vehicle, mice were trained by contextual fear conditioning, during which a mild footshock was delivered (Fig. 3B). The CDPPB- and vehicle-injected mice showed comparable response to the footshock, which stimulated running behavior leading to a momentary increase in locomotion (Fig. 3B; $F_{(1,12)}=0.53, P>0.05$ ). This indicates that CDPPB does not alter sensitivity to the shock-induced pain sensation. When tested $24 \mathrm{~h}$ after the contextual training, CDPPB-injected group displayed more freezing (Fig. 3C) and less movement (Supplemental Fig. S2). Together, these data indicate that enhancement of mGluR5 activity may facilitate the extinction of the old fear memory (Fig. 1A) without hampering new fear memory formation (Fig. 3).
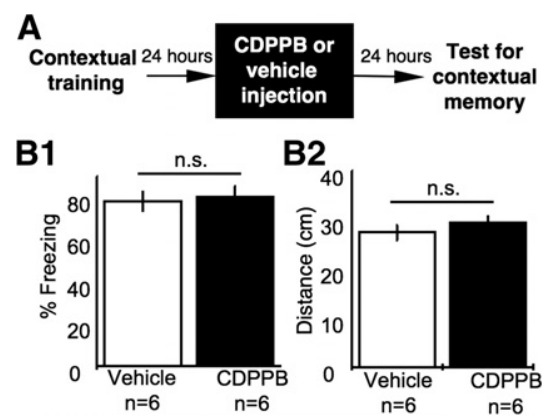

Figure 2. $C D P P B$ does not degrade contextual fear memory. $(A)$ Behavioral and drug administration procedure. (B) Mice were tested 24 $h$ after CDPPB or vehicle injection. Mean \pm SEM of the percentage of freezing $(B 1)$ and distance traveled (B2) per minute during the 2-min memory retention test are presented. (ns) Not significantly different. 


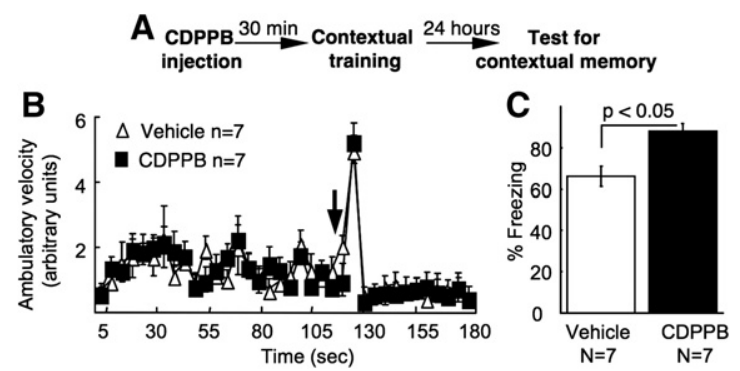

Figure 3. $C D P P B$ facilitates contextual fear memory formation. ( $A$ ) Behavioral and CDPPB administration procedure. (B) Mean \pm SEM of distance traveled for each of the 5-sec bin during the 3-min contextual fear conditioning training. The arrow indicates the delivery of the footshock $(0.7 \mathrm{~mA}, 2 \mathrm{sec}$ duration). (C) Mean \pm SEM of percentage of freezing per minute during the 2-min memory test.

Our data demonstrate that positive modulation of mGluR5 enhances behavioral flexibility, as indicated by that CDPPB facilitates both the initial learning and inhibitory learning during fear memory extinction. This is consistent with the observation that mGluR5 PAMs also enhance synaptic flexibility by facilitating both LTP and LTD (Ayala et al. 2009). Recent studies have shown that mGluR5 PAMs (e.g., CDPPB and ADX47273) enhance both hidden platform and reversal platform learning in the Morris water maze test (Ayala et al. 2009; Xu et al. 2013). By using another mGluR5 PAM, Xu et al. (2013) has found that preextinction administration of ADX47273 fails to enhance the single-session extinction of both contextual and cued fear memory. Further, preor post-extinction injection of ADX47273 also does not affect the multisession extinction of contextual fear memory. It is unknown whether ADX47273 and CDPPB have different pharmacological modality, and whether higher dose of ADX 47273 would show proextinction effect. It is important to note that the study by $\mathrm{Xu}$ et al. (2013) trained mice with three footshocks but we used one shock. It is possible that the stronger conditioned fear may be less sensitive to positive modulation of mGluR5. Interestingly, when ADX47273 is given between the brief memory reactivation/retrieval session and the subsequent extinction session, it causes a weaker recall of the cued fear memory without affecting the freezing behavior within the extinction session. Thus, ADX47273 may facilitate the consolidation of extinction when administered during the reactivation-reconsolidation window (Xu et al. 2013).

In summary, this study, for the first time, demonstrates the effects of mGluR5-positive modulation in both the initial contextual fear memory formation and extinction. As CDPPB enhances fear memory extinction without adversely affecting other aspects of the learning process, our results suggest the application of mGluR5 PAMs as a new potential strategy to enhance the efficacy of exposure therapy and treat anxiety disorders.

\section{Competing interest statement}

The authors declare no conflict of interest.

\section{Acknowledgments}

This study was supported by NIH grant R01MH093445 (H.W.).

\section{References}

Abel T, Nguyen PV, Barad M, Deuel TA, Kandel ER, Bourtchouladze R. 1997. Genetic demonstration of a role for PKA in the late phase of LTP and in hippocampus-based long-term memory. Cell 88: 615-626.
Awad H, Hubert GW, Smith Y, Levey AI, Conn PJ. 2000. Activation of metabotropic glutamate receptor 5 has direct excitatory effects and potentiates NMDA receptor currents in neurons of the subthalamic nucleus. J Neurosci 20: 7871-7879.

Ayala JE, Chen Y, Banko JL, Sheffler DJ, Williams R, Telk AN, Watson NL, Xiang Z, Zhang Y, Jones PJ, et al. 2009. mGluR5 positive allosteric modulators facilitate both hippocampal LTP and LTD and enhance spatial learning. Neuropsychopharmacology 34: 2057-2071.

Choi DC, Rothbaum BO, Gerardi M, Ressler KJ. 2010. Pharmacological enhancement of behavioral therapy: focus on posttraumatic stress disorder. Curr Top Behav Neurosci 2: 279-299.

Cleva RM, Olive MF. 2011. Positive allosteric modulators of type 5 metabotropic glutamate receptors (mGluR5) and their therapeutic potential for the treatment of CNS disorders. Molecules 16: $2097-2106$.

Cleva RM, Hicks MP, Gass JT, Wischerath KC, Plasters ET, Widholm JJ, Olive MF. 2011. mGluR5 positive allosteric modulation enhances extinction learning following cocaine self-administration. Behav Neurosci 125: 10-19.

Difede J, Cukor J, Wyka K, Olden M, Hoffman H, Lee FS, Altemus M. 2014. D-cycloserine augmentation of exposure therapy for post-traumatic stress disorder: a pilot randomized clinical trial. Neuropsychopharmacology 39: 1052-1058.

Fontanez-Nuin DE, Santini E, Quirk GJ, Porter JT. 2011. Memory for fear extinction requires mGluR5-mediated activation of infralimbic neurons. Cereb Cortex 21: 727-735.

Gass JT, Olive MF. 2009. Positive allosteric modulation of mGluR5 receptors facilitates extinction of a cocaine contextual memory. Biol Psychiatry 65: $717-720$

Gass JT, Trantham-Davidson H, Kassab AS, Glen WB Jr, Olive MF, Chandler LJ. 2014. Enhancement of extinction learning attenuates ethanol-seeking behavior and alters plasticity in the prefrontal cortex. J Neurosci 34: 7562-7574.

Ghasemzadeh MB, Vasudevan P, Giles C, Purgianto A, Seubert C, Mantsch JR. 2011. Glutamatergic plasticity in medial prefrontal cortex and ventral tegmental area following extended-access cocaine self-administration. Brain Res 1413: 60-71.

Isiegas C, Park A, Kandel ER, Abel T, Lattal KM. 2006. Transgenic inhibition of neuronal protein kinase A activity facilitates fear extinction. J Neurosci 26: 12700-12707.

Kearns MC, Ressler KJ, Zatzick D, Rothbaum BO. 2012. Early interventions for PTSD: a review. Depress Anxiety 29: 833-842.

Knackstedt LA, Moussawi K, Lalumiere R, Schwendt M, Klugmann M, Kalivas PW. 2010. Extinction training after cocaine self-administration induces glutamatergic plasticity to inhibit cocaine seeking. J Neurosci 30: 7984-7992.

Kufahl PR, Hood LE, Nemirovsky NE, Barabas P, Halstengard C, Villa A, Moore E, Watterson LR, Olive MF. 2012. Positive allosteric modulation of mGluR5 accelerates extinction learning but not relearning following methamphetamine self-administration. Front Pharmacol 3: 194.

Kushner MG, Kim SW, Donahue C, Thuras P, Adson D, Kotlyar M, McCabe J, Peterson J, Foa EB. 2007. D-cycloserine augmented exposure therapy for obsessive-compulsive disorder. Biol Psychiatry 62: $835-838$.

Lecourtier L, Homayoun H, Tamagnan G, Moghaddam B. 2007. Positive allosteric modulation of metabotropic glutamate 5 (mGlu5) receptors reverses $N$-methyl-D-aspartate antagonist-induced alteration of neuronal firing in prefrontal cortex. Biol Psychiatry 62: $739-746$

Lu YM, Jia Z, Janus C, Henderson JT, Gerlai R, Wojtowicz JM, Roder JC. 1997. Mice lacking metabotropic glutamate receptor 5 show impaired learning and reduced CA1 long-term potentiation (LTP) but normal CA3 LTP. J Neurosci 17: 5196-5205.

Maren S. 2011. Seeking a spotless mind: extinction, deconsolidation, and erasure of fear memory. Neuron 70: $830-845$.

Monti B, Berteotti C, Contestabile A. 2006. Subchronic rolipram delivery activates hippocampal CREB and arc, enhances retention and slows down extinction of conditioned fear. Neuropsychopharmacology 31: $278-286$.

Myers KM, Davis M. 2007. Mechanisms of fear extinction. Mol Psychiatry 12: $120-150$.

Myers KM, Carlezon WA Jr, Davis M. 2011. Glutamate receptors in extinction and extinction-based therapies for psychiatric illness. Neuropsychopharmacology 36: 274-293.

Otto MW, Tolin DF, Simon NM, Pearlson GD, Basden S, Meunier SA, Hofmann SG, Eisenmenger K, Krystal JH, Pollack MH. 2010. Efficacy of D-cycloserine for enhancing response to cognitive-behavior therapy for panic disorder. Biol Psychiatry 67: 365-370.

Parsons RG, Ressler KJ. 2013. Implications of memory modulation for post-traumatic stress and fear disorders. Nat Neurosci 16: $146-153$. 
Quirk GJ, Pare D, Richardson R, Herry C, Monfils MH, Schiller D, Vicentic A. 2010. Erasing fear memories with extinction training. J Neurosci 30: 14993-14997.

Rodrigues SM, Bauer EP, Farb CR, Schafe GE, LeDoux JE. 2002. The group I metabotropic glutamate receptor mGluR5 is required for fear memory formation and long-term potentiation in the lateral amygdala. J Neurosci 22: 5219-5229.

Tang YP, Shimizu E, Dube GR, Rampon C, Kerchner GA, Zhuo M, Liu G, Tsien JZ. 1999. Genetic enhancement of learning and memory in mice. Nature 401: 63-69.

Wang H, Ferguson GD, Pineda VV, Cundiff PE, Storm DR. 2004 Overexpression of type-1 adenylyl cyclase in mouse forebrain enhances recognition memory and LTP. Nat Neurosci 7: 635-642.
Xu J, Zhu Y, Contractor A, Heinemann SF. 2009. mGluR5 has a critical role in inhibitory learning. J Neurosci 29: 3676-3684.

Xu J, Zhu Y, Kraniotis S, He Q, Marshall JJ, Nomura T, Stauffer SR, Lindsley CW, Conn PJ, Contractor A. 2013. Potentiating mGluR5 function with a positive allosteric modulator enhances adaptive learning. Learn Mem 20: 438-445.

Yamada D, Zushida K, Wada K, Sekiguchi M. 2009. Pharmacological discrimination of extinction and reconsolidation of contextual fear memory by a potentiator of AMPA receptors. Neuropsychopharmacology 34: $2574-2584$

Received May 24, 2014; accepted in revised form August 20, 2014. 


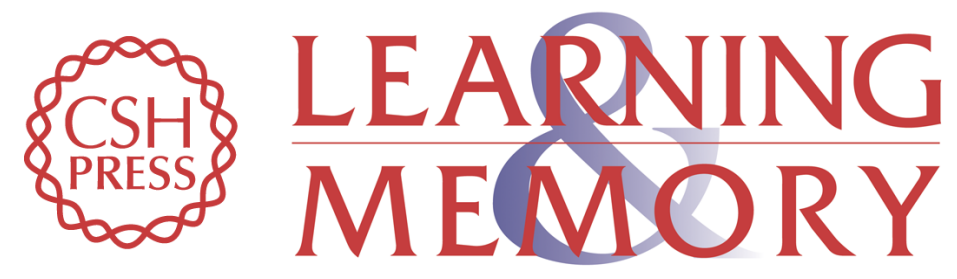

\section{Pharmacological enhancement of mGluR5 facilitates contextual fear memory extinction}

Ferzin Sethna and Hongbing Wang

Learn. Mem. 2014, 21:

Access the most recent version at doi:10.1101/Im.035857.114

\section{Supplemental http://learnmem.cshlp.org/content/suppl/2014/10/23/21.12.647.DC1 Material}

References This article cites 31 articles, 9 of which can be accessed free at: http://learnmem.cshlp.org/content/21/12/647.full.html\#ref-list-1

Creative This article is distributed exclusively by Cold Spring Harbor Laboratory Press for the Commons first 12 months after the full-issue publication date (see

License http://learnmem.cshlp.org/site/misc/terms.xhtml). After 12 months, it is available under a Creative Commons License (Attribution-NonCommercial 4.0 International), as described at http://creativecommons.org/licenses/by-nc/4.0/.

Email Alerting Receive free email alerts when new articles cite this article - sign up in the box at the Service top right corner of the article or click here. 